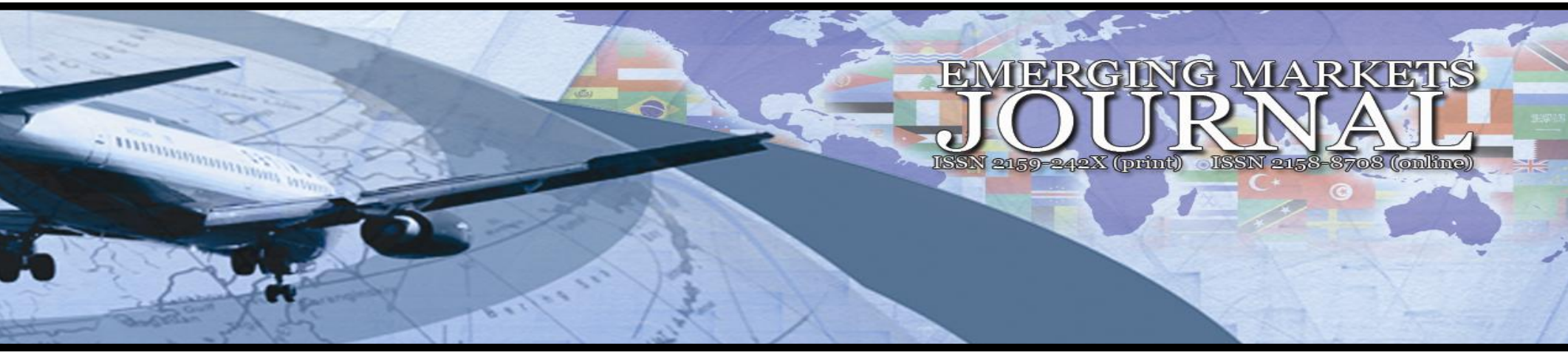

\title{
A Country Specific Approach to IFRS Accounting Policy Choice in the European, Australian and Turkish Context ${ }^{\mathrm{ab}}$
}

\section{Prof. Dr. Nalan AKDOGAN}

Full Professor of Accounting, Baskent University Department of Accounting and Financial Management | email: nalanakdogan@hotmail.com

\section{Assist. Prof. Dr. Can OZTURK}

Assistant Professor of Accounting, Cankaya University Department of Management | email: cozturk@ cankaya.edu.tr

Volume 5 No 1 (2015) ｜ ISSN 2158-8708 (online) ｜ DOI 10.5195/emaj.2015.70 | http://emaj.pitt.edu |

\section{Abstract}

IAS 8 defines the concept of accounting policy as "the specific principles, bases, conventions, rules and practices applied by an entity in preparing and presenting financial statements". Within the framework of this concept, this research that is derived from International Financial Reporting Standards (IFRS) contributes to the accounting literature by focusing on the alternative accounting policies' debate related to presentation and recognition issues in the European, Australian and Turkish context and concludes that there is an influence of local accounting policies over IFRS practice in Turkey and this influence still exists in Europe and Australia based on the 2008/2009 annual reports. This shows that as long as diversity in accounting policies of IFRS is present, entities are expected to be inclined to select their local accounting policies by leading to comparability of financial statements within the country rather than between countries in the IFRS context.

Keywords: Accounting policy, IFRS, Europe, Australia, Turkey

JEL Classification: M41, M48

\section{$(\mathrm{cc})$ EY}

New articles in this journal are licensed under a Creative Commons Attribution 3.0 United States License.

\section{UILIS D-Sonte}

This journal is published by the University Library System of the University of Pittsburgh as part of its D-Scribe Digital Publishing Program, and is cosponsored by the University of Pittsburgh Press. 


\section{A Country Specific Approach to IFRS Accounting Policy} Choice in the European, Australian and Turkish Context

\author{
Prof. Dr. Nalan AKDOGAN \\ Assist. Prof. Dr. Can OZTURK
}

\section{Introduction}

In today's worldwide accounting, the objective of providing understandable, transparent, and comparable financial information as the common denominator of the accounting and financial reporting became an important issue as a result of the increase in commercial activities and foreign direct investments(IASB, 2010: v) because differences in local accounting practices between countries prevent the flow of capital across borders necessary for the optimal allocation of scarce resources in the global context(Ding et al. 2008, 145). In order to achieve this objective, International Accounting Standards Committee(IASC) and subsequently International Accounting Standards Board(IASB) have been working since their inception(Tarca 2005, 67) to prepare International Accounting and Financial Reporting

A Country Specific Approach to IFRS Accounting Policy Choice in the European, Australian and Turkish Context
Standards(IAS-IFRS) that try to reduce the diversity of accounting policies since 1974 .

The objective of this paper is to investigate the trends in alternative accounting policy choices of IFRS related to presentation and recognition in terms of selected European countries, Australia and Turkey to determine whether there is an influence of local accounting practice over IFRS.

This study is important because it proves that as long as the diversity of alternative accounting policy choices exist under IFRS practice, financial statement preparers are expected to be inclined to select the accounting policy choice that specifically refers to their local accounting policy, if any. In this context, this paper proves that the local patterns of IFRS practice is valid for Turkey and local patterns of IFRS practice, still, exist for Australia, France, Britain, Germany and Italy compared to prior research of Kvaal and Nobes(2010) and Nobes(2011).

This research is different from others. First of all, this is the first comprehensive research regarding the trends of accounting policy choices of IFRS in terms of Turkish entities because it not only strengths the findings of Marsap et al.(2007) but also it contributes to the Turkish IFRS accounting policy choice debate in terms of IAS 1, IAS 7, IAS 31, and IAS 40. Second, it considers the trends of accounting policy choices of IFRS that have not been 
mentioned in the papers of Cairns et al.(2008), Mueller et al. (2008), Kvaal and Nobes(2010), Nobes(2011), Kvaal and Nobes(2012), Nobes(2013) regarding the early adoption of IAS 1(2007), IAS 2, and IAS 16 in the general context.

Our observations will be of interest to financial statement preparers and the users of financial information because they provide evidence that if preference is given to local accounting policy under IFRS practice, this situation is expected to make financial statements comparable within the country rather than between countries by leading to consistent use of local accounting policies under IFRS practice.

\section{REVIEW OF ALTERNATIVE ACCOUNTING POLICY DEBATE UNDER IFRS}

IAS 8 defines the concept of accounting policies as "the specific principles, bases, conventions, rules and practices applied by an entity in preparing and presenting financial statements"(IASB 2010, A360). Within the framework of this definition, review of alternative accounting policy debate related to IFRS covers the following studies as far as we are concerned.

For the first time, Marsap et al.(2007) examined the trends in alternative accounting policy choices of IFRS in Turkey in terms of the listed Turkish entities. The sample of this research consists of entities from food, service and textile industries and their financial statements belong to the reporting period ended up December 31, 2006. This research, only, covers the trends in alternative accounting policy choices in terms of IAS 2, IAS 16, IAS 23 and IAS 38.

On the other hand, we pointed out that alternative accounting policy debate related to IFRS keeps going on within the framework of IAS 16, IAS 38 and IAS 40. The selection of historical cost or fair value was tested by Cairns et al.(2008) regarding British and Australian entities, by Mueller et al. (2008) regarding the European real estate sector after IFRS adoption, and by Christensen and Nikolaev(2009) in terms of British and German entities.

The latest research articles that we should mention to finalize alternative accounting policy debate related to IFRS, consist of the research made by Kvaal and Nobes(2010), Nobes(2011), Kvaal and Nobes(2012) and Nobes(2013). Kvaal and Nobes(2010) examined the annual reports of German, French, British, Spanish, and Australian entities to find out the trends of 16 IFRS policy choices and determined that there is a reflection of local accounting policies under IFRS practice. In 2012, they verified that local patterns of accounting policy choice, still, exist for these countries. In addition, Nobes determined that the local patterns of accounting policy choice are valid for Italian, Dutch, and Swedish entities in 2011 and for Canadian entities in 2013 under 14 IFRS policy choices.

\section{DATA AND RESEARCH METHODOLOGY}

\subsection{Sample Set}


The sample of this research is mostly made up of large quoted entities whose financial reporting period ends either in 2008 or 2009 depending on the end of annual accounting period and whose primary operating activities are either manufacturing or providing service or retailing. In addition, our sample is different from prior research because it does not include any financial entities compared to the studies of Cairns et al.(2008), Christensen and Nikolaev(2009), Kvaal and Nobes(2010), Nobes(2011), Kvaal and Nobes(2012) and Nobes(2013) as well as any real estate entities compared to Mueller et al. (2008).

Within the framework of the determinants of our sample set that consist of the market capitalization rate of 54 stock exchanges, IFRS adopted countries and the availability of financial information in English, our sample was formed by the following countries: Germany, France, Britain, Italy, Australia, and Turkey. As a result of this selection, we created a sample consisting of 162 entities as shown in Table 1.

Table 1: Number of Entities Selected from Each Country

\begin{tabular}{|l|c|c|c|c|c|c|}
\hline $\begin{array}{l}\text { Sectors / } \\
\text { Countries }\end{array}$ & $\begin{array}{c}\text { Germ } \\
\text { any }\end{array}$ & $\begin{array}{c}\text { Fran } \\
\text { ce }\end{array}$ & $\begin{array}{c}\text { Brit } \\
\text { ain }\end{array}$ & $\begin{array}{c}\text { Ita } \\
\text { ly }\end{array}$ & $\begin{array}{c}\text { Austr } \\
\text { alia }\end{array}$ & $\begin{array}{c}\text { Turk } \\
\text { ey }\end{array}$ \\
\hline $\begin{array}{l}\text { Manufact } \\
\text { uring }\end{array}$ & 13 & 14 & 17 & 15 & 16 & 23 \\
\hline Service & 8 & 8 & 8 & 8 & 5 & 7 \\
\hline Retailing & 4 & 3 & 4 & 2 & 4 & 3 \\
\hline Total & $\mathbf{2 5}$ & $\mathbf{2 5}$ & $\mathbf{2 9}$ & $\mathbf{2 5}$ & $\mathbf{2 5}$ & $\mathbf{3 3}$ \\
\hline
\end{tabular}

\subsection{Research Method}

This research used the frequency distribution method as the research tool. In this regard, this method helped us to determine the trends in alternative accounting policy choices of IFRS. Based on this method, all empirical results are presented in Table 2.

Table 2: Trends in Alternative Accounting Policy Choices

\begin{tabular}{|c|c|c|c|c|c|c|}
\hline & \multicolumn{6}{|c|}{ Policy trends by country $\%$} \\
\hline & $\begin{array}{c}\text { Germa } \\
\text { ny }\end{array}$ & $\begin{array}{c}\text { Fran } \\
\text { ce }\end{array}$ & $\begin{array}{c}\text { Brita } \\
\text { in }\end{array}$ & $\begin{array}{c}\text { Ital } \\
\mathbf{y}\end{array}$ & $\begin{array}{c}\text { Austra } \\
\text { lia }\end{array}$ & $\begin{array}{c}\text { Turk } \\
\text { ey }\end{array}$ \\
\hline $\begin{array}{l}1 \text { - Early } \\
\text { Adoption of } \\
\text { IAS 1(2007) }\end{array}$ & & & & & & \\
\hline $\begin{array}{l}\mathrm{N}=\text { All } \\
\text { Entities }\end{array}$ & 25 & 25 & 29 & 25 & 25 & 33 \\
\hline $\begin{array}{c}\text { Early } \\
\text { Adopting } \\
\text { Entities }\end{array}$ & $52 \%$ & $48 \%$ & $97 \%$ & $\begin{array}{l}24 \\
\%\end{array}$ & $60 \%$ & - \\
\hline $\begin{array}{c}\text { Non-Early } \\
\text { Adopting } \\
\text { Entities }\end{array}$ & $48 \%$ & $52 \%$ & $3 \%$ & $\begin{array}{l}76 \\
\%\end{array}$ & $40 \%$ & - \\
\hline $\begin{array}{l}2 \text { - Title of } \\
\text { Balance } \\
\text { Sheet }\end{array}$ & & & & & & \\
\hline $\begin{array}{c}\mathrm{N}=\text { Early } \\
\text { Adopting } \\
\text { Entities }\end{array}$ & 13 & 12 & 28 & 6 & 15 & 0 \\
\hline $\begin{array}{c}\text { Balance } \\
\text { Sheet }\end{array}$ & $100 \%$ & $\begin{array}{c}100 \\
\%\end{array}$ & $100 \%$ & $\begin{array}{c}100 \\
\%\end{array}$ & $94 \%$ & - \\
\hline $\begin{array}{c}\text { Statement of } \\
\text { Financial } \\
\text { Position }\end{array}$ & - & - & - & - & $6 \%$ & - \\
\hline $\begin{array}{l}3 \\
\text { Presentation } \\
\text { of Balance } \\
\text { Sheet }\end{array}$ & 25 & 25 & 29 & 25 & 25 & 33 \\
\hline $\begin{array}{l}\mathrm{N}=\text { All } \\
\text { Entities }\end{array}$ & & & & & & \\
\hline $\begin{array}{c}\text { Assets }= \\
\text { Liabilities + } \\
\text { Equity }\end{array}$ & $100 \%$ & $\begin{array}{c}100 \\
\%\end{array}$ & $24 \%$ & $\begin{array}{c}100 \\
\%\end{array}$ & - & $100 \%$ \\
\hline
\end{tabular}




\begin{tabular}{|c|c|c|c|c|c|c|}
\hline $\begin{array}{c}\text { Assets - } \\
\text { Liabilities = } \\
\text { Net } \\
\text { Assets(Equit } \\
\text { y) }\end{array}$ & - & - & $76 \%$ & - & $100 \%$ & - \\
\hline $\begin{array}{l}4 \text { - Order of } \\
\text { Assets and } \\
\text { Liabilities }\end{array}$ & & & & & & \\
\hline $\begin{array}{l}\mathrm{N}=\text { All } \\
\text { Entities }\end{array}$ & 25 & 25 & 29 & 25 & 25 & 33 \\
\hline $\begin{array}{c}\text { Liquidity } \\
\text { Decreasing }\end{array}$ & $16 \%$ & - & $76 \%$ & $8 \%$ & $100 \%$ & $\% 100$ \\
\hline $\begin{array}{c}\text { Liquidity } \\
\text { Increasing }\end{array}$ & $84 \%$ & $\begin{array}{c}100 \\
\%\end{array}$ & $24 \%$ & $\begin{array}{l}92 \\
\%\end{array}$ & - & - \\
\hline $\begin{array}{l}5 \\
\text { Statement of } \\
\text { Comprehens } \\
\text { ive Income }\end{array}$ & & & & & & \\
\hline $\begin{array}{c}\mathrm{N}=\text { Early } \\
\text { Adopting } \\
\text { Entities }\end{array}$ & 13 & 12 & 28 & 6 & 15 & 0 \\
\hline $\begin{array}{c}\text { One - } \\
\text { Statement } \\
\text { Approach }\end{array}$ & - & - & - & - & - & - \\
\hline $\begin{array}{c}\text { Two - } \\
\text { Statement } \\
\text { Approach }\end{array}$ & $100 \%$ & $\begin{array}{c}100 \\
\%\end{array}$ & $100 \%$ & $\begin{array}{c}100 \\
\%\end{array}$ & $100 \%$ & - \\
\hline $\begin{array}{l}6 \\
\text { Traditional } \\
\text { Income } \\
\text { Statement }\end{array}$ & & & & & & \\
\hline $\begin{array}{l}\mathrm{N}=\text { All } \\
\text { Entities }\end{array}$ & 25 & 25 & 29 & 25 & 25 & 33 \\
\hline By Function & $48 \%$ & $52 \%$ & $83 \%$ & $\begin{array}{l}20 \\
\%\end{array}$ & $48 \%$ & $100 \%$ \\
\hline By Nature & $52 \%$ & $48 \%$ & $17 \%$ & $\begin{array}{l}80 \\
\%\end{array}$ & $52 \%$ & - \\
\hline $\begin{array}{l}7 \quad \text { Cost } \\
\text { Flow } \\
\text { Assumptions }\end{array}$ & & & & & & \\
\hline $\begin{array}{l}\mathrm{N}=\text { All } \\
\text { Entities }\end{array}$ & 25 & 25 & 29 & 25 & 25 & 33 \\
\hline WA, only & $52 \%$ & $40 \%$ & $21 \%$ & $\begin{array}{l}68 \\
\%\end{array}$ & $25 \%$ & $88 \%$ \\
\hline FIFO, only & - & $20 \%$ & $32 \%$ & $\begin{array}{l}16 \\
\%\end{array}$ & $46 \%$ & $3 \%$ \\
\hline $\mathrm{WA}+\mathrm{FIFO}$ & $12 \%$ & $8 \%$ & $7 \%$ & $\begin{array}{l}12 \\
\%\end{array}$ & $4 \%$ & - \\
\hline $\begin{array}{c}\text { Undetermine } \\
\mathrm{d}\end{array}$ & $32 \%$ & $32 \%$ & $32 \%$ & $4 \%$ & $13 \%$ & $6 \%$ \\
\hline 8 - Cash & & & & & & \\
\hline
\end{tabular}

\begin{tabular}{|c|c|c|c|c|c|c|}
\hline $\begin{array}{l}\text { Flows from } \\
\text { Operating } \\
\text { Activities }\end{array}$ & & & & & & \\
\hline $\begin{array}{l}\mathrm{N}=\text { All } \\
\text { Entities }\end{array}$ & 25 & 25 & 29 & 25 & 25 & 33 \\
\hline $\begin{array}{c}\text { Direct } \\
\text { Method }\end{array}$ & - & - & $41 \%$ & - & $100 \%$ & - \\
\hline $\begin{array}{l}\text { Indirect } \\
\text { Method }\end{array}$ & $100 \%$ & $\begin{array}{c}100 \\
\%\end{array}$ & $59 \%$ & $\begin{array}{c}100 \\
\%\end{array}$ & - & $100 \%$ \\
\hline $\begin{array}{l}9 \text { - Property, } \\
\text { Plant and } \\
\text { Equipment( } \\
\text { PPE) }\end{array}$ & & & & & & \\
\hline $\begin{array}{l}\mathrm{N}=\text { All } \\
\text { Entities }\end{array}$ & 25 & 25 & 29 & 25 & 25 & 33 \\
\hline Cost Model & $100 \%$ & $84 \%$ & $100 \%$ & $\begin{array}{l}68 \\
\%\end{array}$ & $92 \%$ & $88 \%$ \\
\hline $\begin{array}{c}\text { Cost }+ \\
\text { Revaluation }\end{array}$ & - & - & - & $4 \%$ & $8 \%$ & $12 \%$ \\
\hline $\begin{array}{c}\text { Undetermine } \\
\mathrm{d}\end{array}$ & - & $16 \%$ & - & $\begin{array}{l}28 \\
\%\end{array}$ & - & - \\
\hline $\begin{array}{l}10 \\
\text { Depreciation } \\
\text { Methods in } \\
\text { PPE }\end{array}$ & & & & & & \\
\hline $\begin{array}{l}\mathrm{N}=\text { All } \\
\text { Entities }\end{array}$ & 25 & 25 & 29 & 25 & 25 & 33 \\
\hline Straight-line & $100 \%$ & $92 \%$ & $97 \%$ & $\begin{array}{l}80 \\
\%\end{array}$ & $88 \%$ & $97 \%$ \\
\hline $\begin{array}{c}\text { Straight-line } \\
+ \text { Units of } \\
\text { Production }\end{array}$ & - & $8 \%$ & $3 \%$ & - & $8 \%$ & $3 \%$ \\
\hline $\begin{array}{l}\text { Undetermine } \\
\text { d }\end{array}$ & - & - & - & $\begin{array}{l}20 \\
\%\end{array}$ & - & - \\
\hline $\begin{array}{l}11 \\
\text { Borrowing } \\
\text { Costs }\end{array}$ & & & & & & \\
\hline $\begin{array}{l}\mathrm{N}=\text { All } \\
\text { Entities }\end{array}$ & 25 & 25 & 29 & 25 & 25 & 33 \\
\hline $\begin{array}{l}\text { Benchmark } \\
\text { Treatment }\end{array}$ & $72 \%$ & $44 \%$ & $52 \%$ & $\begin{array}{l}60 \\
\%\end{array}$ & $28 \%$ & $58 \%$ \\
\hline $\begin{array}{c}\text { Alternative } \\
\text { Treatment }\end{array}$ & $24 \%$ & $36 \%$ & $48 \%$ & $\begin{array}{l}40 \\
\%\end{array}$ & $72 \%$ & $39 \%$ \\
\hline $\begin{array}{l}\text { Undetermine } \\
\mathrm{d}\end{array}$ & $4 \%$ & $20 \%$ & - & - & - & $3 \%$ \\
\hline $\begin{array}{l}12 \\
\text { Investment } \\
\text { in Joint - } \\
\text { Ventures }\end{array}$ & & & & & & \\
\hline $\begin{array}{c}\mathrm{N}=\text { Entities } \\
\text { with Joint }\end{array}$ & 17 & 13 & 19 & 16 & 13 & 12 \\
\hline
\end{tabular}




\begin{tabular}{|c|c|c|c|c|c|c|}
\hline Ventures & & & & & & \\
\hline $\begin{array}{c}\text { Proportionate } \\
\text { Consolidatio } \\
n\end{array}$ & $42 \%$ & $85 \%$ & $32 \%$ & $\begin{array}{l}44 \\
\%\end{array}$ & $8 \%$ & $83 \%$ \\
\hline $\begin{array}{l}\text { Equity } \\
\text { Method }\end{array}$ & $58 \%$ & $15 \%$ & $58 \%$ & $\begin{array}{l}56 \\
\%\end{array}$ & $92 \%$ & $17 \%$ \\
\hline $\begin{array}{l}\text { Undetermine } \\
\qquad \mathrm{d}\end{array}$ & - & - & $10 \%$ & - & - & - \\
\hline $\begin{array}{l}13 \\
\text { Intangible } \\
\text { Assets }\end{array}$ & & & & & & \\
\hline $\begin{array}{l}\mathrm{N}=\text { All } \\
\text { Entities }\end{array}$ & 25 & 25 & 29 & 25 & 25 & 33 \\
\hline Cost Model & $100 \%$ & $40 \%$ & $97 \%$ & $\begin{array}{l}44 \\
\%\end{array}$ & $80 \%$ & $97 \%$ \\
\hline $\begin{array}{c}\text { Undetermine } \\
\mathrm{d}\end{array}$ & - & $60 \%$ & $3 \%$ & $\begin{array}{l}56 \\
\%\end{array}$ & $20 \%$ & $3 \%$ \\
\hline $\begin{array}{l}14 \\
\text { Investment } \\
\text { Property }\end{array}$ & & & & & & \\
\hline $\begin{array}{c}\mathrm{N}=\text { Entities } \\
\text { with } \\
\text { Investment } \\
\text { Properties }\end{array}$ & 10 & 7 & 4 & 6 & 1 & 15 \\
\hline Cost Model & $100 \%$ & $86 \%$ & $100 \%$ & $\begin{array}{c}100 \\
\%\end{array}$ & - & $67 \%$ \\
\hline $\begin{array}{c}\text { Fair Value } \\
\text { Model }\end{array}$ & - & $14 \%$ & - & - & $100 \%$ & $33 \%$ \\
\hline
\end{tabular}

\section{EMPIRICAL RESULTS AND DISCUSSION}

\subsection{IAS 1 Presentation of Financial Statements}

Under IAS 1(2007), we determined 5 accounting policies of which 2 of them were observed in terms of the early adopting entities of IAS 1(2007) and 3 of them were examined in terms of all entities as the following.

\section{Title of Balance Sheet: IAS 1(2007) provides} financial statement preparers the opportunity to call this statement as "Statement of Financial Position" rather than
Balance Sheet(IASB 2010, A296). For this reason, we questioned the following hypothesis:

H1: Early adopting entities of IAS 1(2007) are inclined to use the title "Statement of Financial Position" rather than "Balance Sheet"

Within the framework of this hypothesis, we determined that all early adopting entities from Germany, France, Italy and United Kingdom are inclined to use the title "Balance Sheet", because this title is generated from their local accounting practice due to the reflection of the 4th Directive of the European Council. Therefore, it seems that early adopting countries from Europe are conservative in this context. However, it is expected that Australian entities would be willing to use the title "Statement of Financial Position" due to their local accounting practice regulated by the former standard AASB 1040 Statement of Financial Position.

\section{Presentation of Balance Sheet: IAS 1 does} not prescribe any format of balance sheet(IASB 2010, A303). For this reason, we pointed out that presentation of balance sheet is diversified. That's why, we questioned the following hypothesis:

H2: Turkish and European entities except some of British ones are fully inclined to use the format of "Balance Sheet" that refers to "Assets = Liabilities + Equity" ${ }^{\mathrm{c}}$ rather than "Assets - Liabilities = Net Assets(Equity)" ${ }^{d}$. 
3. Liquidity Order: IAS 1 requires the use of current/non-current distinction but entities are free to classify their assets and liabilities on the balance sheet either in liquidity decreasing or liquidity increasing order(IASB 2010, A304). For this reason, we observed that classification of assets and liabilities is diversified. For this reason, we questioned the following hypothesis:

H3: European entities except majority of British ones are inclined to classify their assets and liabilities in liquidity increasing order compared to Australian, Turkish and minority of British ones that prefer liquidity decreasing order.

These two hypotheses were accepted by our findings and due to the diversity of the format of balance sheet and the liquidity order; we analyzed $\mathbf{H 2}$ and $\mathbf{H 3}$ on a country basis as follows.

France: French regulations on consolidated accounts are in favor of the preparation of a consolidated balance sheet either by term or by nature while imposing the format by nature since 2000(Ding et al. 2008, 147). Even if this is the case, preference was still given to the consolidated balance sheet by term(Ding et al. 2008, 147). By term is also a reflection of Article 9 of the 4th Directive which refers to non-current/current distinction over the French local accounting practice because accounting regulation in France was essentially influenced by European directives and regulations(Bocqueraz 2010, 51). In this regard, our results show that French entities, still, keep their format of their consolidated balance sheets by term under IFRS practice.
Italy: In Italy, accounting regulation was strongly improved by the 4th Directive and Article 9 of this Directive was approved as the local balance sheet format(Cameran and Pettinicchio 2010, 100-101). In this context, our results reflect the influence of this local balance sheet format over the IFRS practice.

Germany: Before the adoption of IFRS in 2005, German entities whose shares that were quoted in stock exchange, were authorized to prepare either US GAAP or IFRS based financial statements(Beckman et al. 2007, 254). That's why, the companies whose financial reporting was US GAAP or IFRS based, prepared their balance sheets according to US GAAP format or according to the Article 9 of the 4th Directive. In this regard, given the flexibility provided by IFRS practice to present a specific format of balance sheet, our results indicate that some German entities, still, use US GAAP format of balance sheet under IFRS practice as a reflection US GAAP over IFRS.

Britain: British accounting system has been influenced by the 4th Directive. Companies Act 1981 introduced new formats of balance sheet(Napier 2010, 266). As of 2008, related British regulations provide two formats of balance sheet which refer to Article 9 and 10 of the 4th Directive. However, many companies do not absolutely and precisely use these formats(Nobes and Parker 2008, 336). As a reflection of this situation, we observed that the majority of British entities use the Anglo- 
Saxon balance sheet ${ }^{\mathrm{e}}$ format which creates the concept of "net assets" rather than "net current assets" as it is in Article 10. Our results indicate that the adoption of Anglo-Saxon balance sheet is stronger than the adoption of European one in Britain.

Australia: Before the full adoption of IFRS, presentation of balance sheet in Australian local accounting practice was regulated by the former accounting standard AASB 1040 Statement of Financial Position that provides two formats either by term or by nature. Also, a balance sheet by term can be presented based on either US GAAP or Anglo-Saxon format. In this context, our results show that Australian entities prefer the Anglo-Saxon format ${ }^{\mathrm{f}}$. This constitutes a reflection of local accounting practice over IFRS practice.

Turkey: Since 1960s, Turkish accounting regulations have been established based on the United States model(Catalin Nicolae Albu et al. 2013, 150) because successful individuals that have been trained and have taken graduate degrees from the late 1950s, particularly, in the US, implemented their accounting expertise over the Turkish accounting system and a uniform chat of accounts was developed for state economic enterprises in 1974 under the heavy influence of the American system(Simga-Mugan 1995, 354). That's why, a US GAAP based balance sheet was adopted in Turkey. In 1992, the first Communiqué on Accounting System that regulates local accounting system, was published under the influence of the 4th Directive; however, the format of the balance sheet has been kept(Akdogan 1991, 26). In this context, our observations indicate that Turkish entities still present their balance sheets according to the existing format as a reflection of local accounting practice over IFRS.

\section{Presentation of Statement of Comprehensive}

Income: This is a new financial statement under IFRS and became compulsory via IAS 1 (2007). It can be presented either as a single statement or as two separate statements(traditional income statement and statement of comprehensive income)(IASB 2010, A308). In this context, we questioned the following hypothesis:

H4: Early adopting entities of IAS 1(2007) are inclined to use two statement approach rather than one statement approach.

Our observations accepted this hypothesis, because we determined that all early adopting entities prefer two statement approach. The reasons behind this preference are based on the fact that this financial statement does not exist in local accounting practice of all countries except Britain and entities do not want to make any complicated presentation of profit/loss for the period and total comprehensive income. On the other hand, this statement 
was regulated by the former accounting standard FRS 3 Reporting Financial Performance in Britain according to two statement approach(Accounting Standards Board 1992, 32). Since our results show that all early adopting British entities prefer the two statement approach, this is a reflection of local accounting practice over IFRS.

\section{Presentation of Traditional Income}

Statement: According to IAS 1, traditional income statement can be prepared either by function or by nature(IASB 2010, A312). In this context, we questioned the following hypothesis:

H5: All entities are inclined to prepare their income statements by function rather than by nature

Our observations rejected this hypothesis within the framework of the following cases:

France: In French accounting practice, even though an individual income statement by nature is required, a consolidated income statement either by function or by nature can be prepared(Ding at al. 2008, 147). In this context, our results show that French entities do not strongly dominate an income statement either by function or by nature.

Italy: In Italy, an income statement can only prepared by nature(Cameran and Pettinicchio 2010, 101). As a reflection of this local accounting practice, we observed that the majority of Italian entities are inclined to report their income statement by nature under IFRS practice.

Germany: In German accounting practice, even if an income statement by function or by nature is allowed, the most widely selected format has been by nature(Nobes and Parker 2008, 46). In addition, we should recall that financial reporting based on either US GAAP or IFRS have been permitted until the adoption of EU-Adopted IFRS for the listed entities. Within the framework of this analysis, our findings indicate that an income statement by nature does not strongly dominate an income statement by function under IFRS practice and even we can relatively say that entities selected an income statement by function would be the ones that switched from US GAAP to IFRS because an income statement by function is the most preferred under US GAAP(Meek 2003, 81).

Britain: In Britain, entities are allowed to prepare their income statements either by function or by nature under local accounting practice according to the former standard FRS 3 but the most accepted format is by function(Walton 2003, 166). In this regard, our results prove that the majority of British entities are inclined to prepare an income statement by function as a reflection of British local accounting over IFRS.

Australia: According to the local accounting practice in Australia, entities are allowed to prepare an income statement either by function or by nature according to the former standard AASB 1018 Statement of Financial Performance. In this context, our results show that an income statement either by function or by nature does not strongly dominate with each other.

Turkey: Under local accounting regulations in Turkey, particularly, generated from the influence of US 
GAAP that we have mentioned before(Catalin Nicolae Albu et al, 2013: 150), entities can prepare an income statement by function, only(Koc Yalkin 1991, 89). This accounting policy, also, exists in the first Communiqué on Accounting System as the influence of the Article 25 of the 4th Directive(Koc Yalkin 1991, 88). In this context, we pointed out that all Turkish entities continue to prepare an income statement by function as a reflection of local accounting practice over IFRS.

\subsection{IAS 2 Inventory}

IAS 2 permits the use of the following cost flow assumptions: Specific Identification Method, First-in Firstout(FIFO) and Weighted Average(WA)(IASB 2010, A333). By taking these accounting policies into account, we questioned the following hypothesis:

H6: The continental European and Turkish entities are more inclined to use WA method rather than FIFO as done by Anglo-Saxon entities

Our observations accepted this hypothesis within the framework of the following cases:

In Europe, the 40th Article of the 4th Directive regulates the inventory costing methods as Specific Identification Method, FIFO, LIFO and WA; however, LIFO method has been eliminated since 2003 as part of IFRS(Jaafar and Mcleay 2007, 156).
France: In French local accounting practice, entities can use FIFO, LIFO or WA. According to the research of Jaafar and Macleay(2007), WA and FIFO are, respectively, the most preferred methods of inventory costing and this study indicates that French entities gradually moved from LIFO to either WA or FIFO. In this context, our observations indicate that French entities are inclined to select WA rather than FIFO as it was before as a reflection of local accounting practice over IFRS.

Italy: Under Italian local accounting practice, FIFO, LIFO and WA are allowed and LIFO is the most widely used in practice(Zambon 2003, 209); however, while the process of eliminating LIFO has been in progress from 1995 to 2004 as part of IFRS, the study of Jaafar and Mcleay(2007) indicates that Italian entities, gradually, switched from LIFO to either WA or FIFO. In this context, our findings show that the majority of Italian entities(WA + $(\mathrm{WA}+\mathrm{FIFO}))$ are inclined to prefer WA as the inventory costing method.

Germany: According to German accounting practice, FIFO, LIFO and WA are allowed(Haller 2003, 118); however, WA method is common under local practice(Nobes and Parker 2008, 150). In addition, the research of Jaafar and Mcleay(2007) verifies this fact. In this regard, our results indicate that the majority of German entities $(\mathrm{WA}+(\mathrm{WA}+\mathrm{FIFO}))$ are inclined to prefer WA as a reflection of local accounting practice over IFRS. 
Britain: In Britain, FIFO and WA are allowed except LIFO(Nobes and Parker 2008, 82). But, FIFO is the most widely preferred method under local accounting practice(Walton 2003, 169). This is also proved by study of Jaafar and Mcleay(2007). In this context, our observations indicate that British entities are inclined to select $\mathrm{FIFO}(\mathrm{FIFO}+(\mathrm{FIFO}+\mathrm{WA}))$ as a reflection of local accounting practice over IFRS.

Australia: Inventory costing methods are locally regulated by the former standard AASB 1019 Inventories. In this context, FIFO and WA are allowed, only. According to Heazlewood(2003), the predominant measures of cost were WA(32\%) and FIFO(42\%) in 1999. Under the IFRS practice, our results indicate, almost, the same tendency as a reflection of local accounting practice over IFRS.

Turkey: In Turkey, WA and FIFO are solely allowed under local accounting practice according to Turkish Tax Procedure Law. Our results indicate that the majority of Turkish entities prefer the WA method under IFRS practice.

\subsection{IAS 7 Statement of Cash Flows}

IAS 7 regulates the principles to prepare a statement of cash flows(IASB 2010, A342). The following accounting policy was questioned under IAS 7.

6. Direct or Indirect Method: In terms of financial reporting, cash flows from operating activities can be prepared according to direct or indirect method(IASB
2010, A346). Since this is the case, we questioned the following hypothesis:

H7: All entities are inclined to report cash flows from operating activities by using the direct method rather than indirect method

Our observations rejected this hypothesis within the framework of the following cases:

France: In France, Regulation 99-02 provides guidance on how to prepare a statement of cash flows in terms of consolidated accounts under local accounting practice. In this context, either direct or indirect method can be used to report the cash flows from operating activities. However, Recommendation 2004-R-02, 2009-R-03 and 2013-03 does not even mention direct method and states that indirect method is the most appropriate to determine the cash flows. For this reason, our observations indicate that all French entities are inclined to choose indirect method as a reflection of local accounting practice over IFRS.

Italy: Under local accounting practice in Italy, standard 12 offers three different statements of cash flows that one of them is particularly similar to IAS 7(OIG 2005, 84). In this context, either direct or indirect method can be used to report the cash flows from operating activities; however, this standard forwards financial statement preparers to select indirect method by stating that the application of direct method is more complex than the other. Within this framework, our findings show that all Italian entities preferred the indirect method as a reflection of local accounting practice over IFRS. 
Germany: Statement of cash flows is required in terms of consolidated financial statements and regulated by the GAS 2 Cash Flow Statements under local accounting practice. Reporting cash flows are similar to IAS 7 and cash flows from operating activities can be presented using either the direct method or indirect method. This standard does not push the financial statement preparers to use any one of these methods. On the other hand, indirect method is the most preferred under US GAAP(Meek 2003, 84). For this reason, if it is assumed that German entities whose financial reporting that was based on US GAAP before the EU-adopted IFRS had reported their cash flows from operating activities under indirect method, this constitutes a reflection of US GAAP over IFRS practice. Within this framework, our findings show that German companies are significantly inclined to use the indirect method in the reporting of cash flows from operating activities.

Britain: In British local accounting practice, the former standard FRS 1 Cash Flow Statements regulates this financial statement. In this context, all cash flows are reported under similar practice given in IAS 7; however, the reporting structure of cash flows from operating activities is different from IAS 7 and cash flows from operating activities can be reported using either direct or indirect method. On the other hand, this standard forwards the financial statement preparers to use indirect method unless the benefit of reporting cash flows from operating activities under direct method exceeds the cost of acquisition of this benefit(Accounting Standards Board, 1996: 65). For this reason, our results show that British entities are significantly inclined to use indirect method as a reflection of local accounting practice over IFRS.

Australia: Statement of cash flows is locally regulated by the former standard AASB 1026. It similarly reports all cash inflows and cash outflows according to IAS 7. To report the cash flows from operating activities, the direct method is allowed only. In this context, our observations indicate that Australian entities are significantly inclined to report their cash flows from operating activities under direct method as a reflection of local accounting practice over IFRS.

Turkey: In Turkey, statement of cash flows had not been a compulsory financial statement until IFRSs were adopted; however, it was regulated by the first Communiqué on Accounting System as one of the supplementary financial statements(Simga-Mugan 1995, 357). Compared to the statement of cash flows in IAS 7, all cash inflows and outflows were not classified and were prepared according to direct method(Akdogan ve Tenker. 2006, 286-287). However, our results show that Turkish entities are inclined to use indirect method under IFRS practice. 


\subsection{IAS 16 Property, Plant and Equipment}

\section{Valuation after initial recognition:}

Property, plant and equipment are measured either according to cost or revaluation model(IASB 2010, A448). In this context, we questioned the following hypothesis:

H8: Entities whose local accounting practice permits revaluation model are inclined to prefer revaluation rather than cost model under IFRS practice compared to other entities whose local accounting practice is based on cost model

This hypothesis was rejected within the framework of the following cases:

France: In France, revaluation is possible as replacement cost or historical cost adjusted for general price inflation in the context of consolidated financial statements. However, French entities do not prefer these alternative valuation options(Hoarau 2003, 148). This indicates that the common practice is the cost model under local accounting. In this regard, our data indicates that French entities are inclined to select cost model as a reflection of local accounting practice over IFRS. On the other hand, we observed that a number of French entities did not pay attention to state their accounting policy.

Italy: Under Italian local accounting practice, revaluation is allowed under exceptional circumstances(Zambon 2003, 210). That's why, it is not a common practice. In this context, we observed that Italian entities are inclined to use cost model under IFRS but a considerable percentage of Italian entities did not express their accounting policy in this context.

Germany: In Germany, revaluation is not allowed under local accounting practice(Haller 2003, 121). On the other hand, German listed entities whose financial reporting based on US GAAP before the EU-adopted IFRS, also, implemented cost model because revaluation is prohibited under US GAAP(Meek 2003, 82). Within this framework, we pointed out that German entities are inclined to prefer cost model as a reflection of both local accounting practice and US GAAP over IFRS.

Britain \& Australia: In Britain and Australia, revaluation was respectively regulated by the former standard FRS 15 Tangible Fixed Assets and AASB 1041 Revaluation of Non-Current Assets. Due to this fact, it is estimated that British and Australian entities are inclined to choose revaluation model under IFRS practice. However, our findings show that British and the majority of Australian entities prefer the cost model as a conservative approach under IFRS.

Turkey: In Turkey, revaluation is an accounting policy that has to be implemented under inflationist periods(Simga-Mugan 2002, TRK-30). That's why, cost model rather than revaluation is the common practice under Turkish local accounting. Within this framework, we observed that the majority of Turkish entities are inclined to use cost model as a reflection to local practice over IFRS. 
8. Depreciation: According to IAS 16, the allowed methods of depreciation are straight-line, double declining balance and units of production(IASB 2010, A452). Based on this accounting policy, we provided the following hypothesis:

H9: Entities are inclined to use the same accounting policy to depreciate their property, plant and equipment after the adoption of IFRS except some sectorspecific circumstances

This hypothesis was accepted within the framework of the analysis of the following cases:

France \& Germany: In terms of the local accounting practice of France and Germany, prior research indicates that the combination of straight-line and double-declining methods has been essentially a common practice, because of the potential tax savings(Jaafar and Mcleay 2007, 184). However, our findings show that straight-line became the dominant method under IFRS practice. In addition, we determined that French resource-based entities use the units of production method.

Italy: Former research shows that the straight-line method is the common practice in Italy(Jaafar and Mcleay 2007, 184) with respect to local accounting. In this context, our data indicates that straight-line is the most preferred method of depreciation as an evidence of local accounting practice over IFRS. On the other hand, we pointed out that
$20 \%$ of Italian entities did not attach necessary importance to express their accounting policy regarding depreciation.

Britain: In British local accounting practice, FRS 15 regulates the depreciation methods as straight-line and reducing balance. In this context, the ex-post results of prior literature (Jaafar and Mcleay 2007, 184) determined that straight-line is the typical method of depreciation in Britain. Also, our findings are in parallel to these results as an evidence of local accounting practice over IFRS.

Australia: In Australia, depreciation was regulated by the former standard AASB 1021 Depreciation under local practice. Three methods were offered: straight-line, reducing balance and a method of overall output or service which the asset is expected to yield to the entity, for example, estimated production units, operating hours or distance travelled. In this context, it is known that the straight-line method constitutes the common practice (Heazlewood 2003, 292). Within the framework of this fact, our findings proved that straight-line method is still the dominant practice for Australian entities as a reflection of local accounting practice over IFRS. Also, we determined that resources-based entities use units of production method in addition to straight-line.

Turkey: Under local accounting practice in Turkey, 
depreciation(normal depreciation) and double declining, only(Simga-Mugan 2002, TRK-18). Our findings show that straight-line depreciation is the dominant practice in Turkey under IFRS practice. In addition, a limited number of entities operated in resource-based industries started to use units of production method under IFRS practice.

\subsection{IAS 23 Borrowing Costs}

\section{Benchmark treatment and alternative}

treatment: IAS 23 had two methods to recognize the borrowing costs which were benchmark treatment and alternative treatment until the cancellation of benchmark treatment in 2009. Since this research data covers the period before the adoption of new IAS 23, we questioned the following hypothesis:

H10: Australian entities are inclined to choose alternative treatment rather than benchmark treatment compared to other entities

This hypothesis was accepted by taking the capitalization of interest into account. In this context, we pointed out that the local accounting policy of Australia on borrowing costs regulated by the former standard AASB 1036 Borrowing Costs is in conformity with IAS 23's alternative treatment because it requires the capitalization of the interest if borrowing costs are directly attributable to the acquisition, construction or production of a qualifying asset. For this reason, alternative treatment is the dominant practice in Australia as a reflection of local accounting over IFRS. On the other hand, even if capitalization of interest was defined, it remained probable or uncommon under local accounting practice in France(Stolowy 2002, FRA34), Germany(Haller 2003, 118), Italy(Andrei and Bisaschi 2002, ITA-19) and United Kingdom(Walton 2003, 167). In Turkey, capitalization of interest is limited and only interest costs incurred during construction are capitalized (SimgaMugan 2002, TRK-16). In this context, generally speaking, our observations indicate that benchmark treatment is the dominant practice in other countries.

\subsection{IAS 31 Investments in Joint-Ventures}

\section{Proportionate consolidation or equity method:}

The recognition of joint-ventures has been regulated by the new standard IFRS 11 Joint Arrangements and IAS 28 Investments in Associates and Joint-Ventures starting from 2013 by cancelling the proportionate consolidation. Even if this is the case, this research is based on the time period that both methods existed under IAS 31(IASB 2010, A665). That's why, we questioned the following hypothesis.

H11: French entities are inclined to choose proportionate consolidation as a reflection of local accounting policy over IFRS.

H12: British and Australian entities are inclined to select equity method as a reflection of local accounting policy over IFRS.

Both hypotheses were accepted within the framework of the analysis of the following cases:

France: In France, proportionate consolidation is the only local accounting policy to recognize joint-ventures on a balance sheet(Stolowy 2002, FRA-60). In this regard, our data indicate that the majority of French entities prefer 
proportionate consolidation under IFRS practice as an influence of local accounting practice over IFRS.

Italy: Both proportionate consolidation and equity method are acceptable under local accounting practice(Zambon 2003, 207). Our findings show that Italian entities are inclined to select equity method rather than proportionate consolidation.

Germany: Joint-ventures are recognized by using proportionate consolidation in accordance with GAS 9 Accounting for Investments in Joint-Ventures in Consolidated Financial Statements under local accounting practice. It is common under German accounting practice(Alexander and Nobes 2007, 284) However, our observations show that equity method is more preferable than proportionate consolidation. In this context, even if there are still some German entities that use proportionate consolidation as a reflection local accounting practice over IFRS, we should recall that there were listed German entities whose financial reporting based on US GAAP before the EU-adopted IFRS. For these entities, equity method was the sole method to recognize joint-ventures under US GAAP(Meek 2003, 85). That's why; it is possible to state that this is an influence of US GAAP over IFRS practice.
Britain: According to the local accounting practice in Britain, proportionate consolidation has not been acceptable but it is available in companies act published in 1989(Walton 2003, 167). Within the framework of this fact, we observed that equity method is still dominant practice in Britain as a reflection of local accounting practice over IFRS. On the other hand, a limited number of joint-ventures did not express their accounting policy in this context.

Australia: Under Australian local accounting practice, interests in joint-ventures are regulated by the former standard AASB 1006 which states that jointventures are recognized in accordance with equity method. In this context, our results show that equity method is common in Australia as a reflection of local accounting practice over IFRS.

Turkey: In Turkey, there is no local accounting policy to recognize joint-ventures as stated in IAS 31 . On the other hand, under IFRS practice, preference was given to proportionate consolidation.

\subsection{IAS 38 Intangible Assets}

\section{Valuation after initial recognition:}

According to IAS 38, intangible assets are valued using either the cost model or the revaluation model. In this 
context, we questioned the following hypothesis as the following:

H13: Entities whose local accounting practice allows revaluation model are inclined to prefer revaluation under IFRS practice.

H14: Entities whose local accounting practice allow cost model are inclined to prefer revaluation model under IFRS practice.

Both hypotheses were rejected within the framework of the analysis of the following cases:

France \& Italy: In France, local accounting practice does not allow to recognize intangible assets above cost(Tarca 2005, 79). In Italy, revaluation of intangible assets is not allowed except when an ad hoc revaluation law is issued(Zambon 2003, 213). As an evidence of the influence of local accounting practice over IFRS, our results show that French and Italian entities prefer the cost model.

Germany: Under local accounting practice in Germany, intangible assets cannot be revalued(Tarca, 2005: 79). In addition, listed German entities whose financial reporting based on US GAAP before the EU-adopted IFRS had to apply cost model as an accounting policy because US GAAP prohibits the revaluation model(Tarca, 2005: 71). In this context, we pointed that German entities prefer the cost model as a reflection of both local accounting practice and US GAAP over IFRS.

Britain \& Australia: Both countries allow revaluation under their local accounting practices(Tarca,
2005: 71). However, our observations indicate that British and Australian entities are inclined to select cost model under IFRS practice as a conservative approach.

Turkey: In Turkey, the revaluation of the intangible assets is not allowed(Simga-Mugan 2002, TRK-30). For this reason, Turkish entities prefer cost model as a reflection of local accounting practice over IFRS.

Overall, the analysis that we pointed out above also indicates that there is no active market for these assets such that their fair values of intangible assets can be relatively easily determined according to IAS 38(IASB 2010, A859).

\subsection{IAS 40 Investment Property}

12. Valuation after initial recognition: Items of investment property are valued according to cost model or fair value model(IASB 2010, A974). In this regard, we questioned the following hypothesis by taking the sample size into account:

H15: Entities whose local accounting policy for property, plant, and equipment is at cost are inclined to select cost model for their investment properties under IFRS practice.

H16: Entities whose local accounting policy for investment properties allows fair value model are inclined to select fair value model for their investment properties under IFRS practice.

First hypothesis was accepted in terms of German and Turkish entities because there is no investment 
property classification under German and Turkish local accounting practice(Ozturk 2009, 101). That's why, investment properties were classified under property, plant and equipment at cost, only. Under IFRS practice, they were reclassified. In this context, the sample size is relatively meaningful to state that there is a reflection of local accounting policy over IFRS because they are valued at cost.

The latter hypothesis may be accepted in terms British entities due to the fact that these assets were classified as investment properties under local practice(Ozturk 2009, 101-103) and regulated by the former standard SSAP 19 Investment Properties that is based on fair value. That's why, it is highly expected that British entities will continue to select fair value model under IFRS practice.

\section{CONCLUSION}

In this research, we observed the trends of 12 accounting policy choices under IFRS practice in the European, Australian and Turkish context based on the 2008/2009 annual reports and the following conclusions were drawn:

In terms of alternative accounting policy choices of IFRS, we determined for the first time that the influence of local accounting policies over IFRS is valid for Turkish entities and we pointed out that the influence of local accounting policies over IFRS, still, exists in the European and Australian context compared to prior research.

Due to the diversification of accounting policy choices and the reflection of local accounting policies over IFRS, we pointed out that the comparability of financial statements are mostly possible within the country rather than between countries.

In order to make the financial reporting globally comparable in the IFRS context, accounting policy choices should be eliminated. A specific format of balance sheet should be introduced. Income statement by function or nature and cost flow assumptions should be selected on a sector specific basis rather than country specific. Direct method of cash flow statement should be adopted to provide relevant information related to operating cash flows. Accounting policies should be clearly stated in the notes of financial statements. Otherwise, it looks like that IFRS will remain as a "title" common denominator of international financial reporting. 


\section{REFERENCES}

AASB. 1997a. AASB 1026 Statement of cash flows. Available from: <http://www.aasb. com.au/admin/file/content102/c3/AASB1026_1097.pdf> [Accessed April 2011].

AASB. 1997b. AASB 1036 Borrowing costs. Available from: $\quad<h t t p: / / w w w . a a s b$. com.au/admin/file/content102/c3/AASB1036_1297.pdf> [Accessed April 2011]..

AASB. 1997c. AASB 1021 Depreciation. Available from: <http://www.aasb. gov.au/admin/file/content102/c3/AASB1021_897.pdf $>$ [Accessed January 2014].

AASB. 1998a. AASB 1006 Interests in Joint-Ventures. Available $\quad$ from: $\quad<$ http://www.aasb. gov.au/admin/file/content102/c3/AASB1006_1298.pdf > [Accessed January 2014].

AASB. 1998b. AASB 1019 Inventories. Available from: <http://www.aasb.gov.au/admin/ file/content102/c3/AASB1019_3-98.pdf> [Accessed January 2014].

AASB. 1999. AASB 1040 Statement of financial position. Available from: <http://www.aasb. com.au/admin/file/content102/c3/AASB1040_1099.pdf> [Accessed April 2011]..

AASB. 2001. AASB 1041 Revaluation of Non_Current Assets. Available from: <http://www.aasb.gov.au/admin/file/content102/c 3/AASB1041_07-01.pdf> [Accessed July 2013].

AASB. 2002. AASB 1018 Statement of Financial Performance. Available from: <http://www.
aasb.gov.au/admin/file/content102/c3/AASB1018 _06-02.pdf> [Accessed July 2013].

Accounting Standards Board. 1992. FRS 3 Reporting Financial Performance. United Kingdom. Available from: <http://www.frc.org.uk/OurWork/Pub lications/ASB/FRS-3-ReportingFinancial-Performance/FRS-3-ReportingFinancial-Performance.aspx $>$ [Accessed January 2014].

Accounting Standards Board. 1996a. SSAP 19 Accounting for Investment Properties. United Kingdom. Available from: <http://frc.org.uk/OurWork/Publications/ASB/SSAP-19-Accountingfor-investment-proper ties-File.pdf> [Accessed January 2014].

Accounting Standards Board. 1996b. FRS 1 Cash Flow Statements. United Kingdom. Available from:<http://www.frc.org.uk/Our-

Work/Publications/ASB/FRS-1-(Revised-1996)-

CashFlow-Statements/FRS-1-Cash-Flow-

Statements.aspx> [Accessed January 2014].

Accounting Standards Board. 1999. FRS 15 Tangible Fixed Assets. United Kingdom. Available from: <http://www.frc.org.uk/getattachment/49cd6559ed66-4a22-9866ea 01bf9a3b58/FRS-15Tangible-Fixed-Assets.aspx > [Accessed January 2014].

Accounting Standards Committee of Germany. 1999. GAS 2 Cash Flow Statements. Available from: <http://www.drsc.de/service/drs/standards/index_ 
en.php?ixstds_do $=\quad$ show_details\&entry_id $=3>$

[Accessed January 2014].

Accounting Standards Committee of Germany. 2001. GAS

9Accounting for Investments in Joint Ventures in Consolidated Financial Statements. Available from:

<http://www.drsc.de/service/drs/standards/index_ en.php?ixstds_do=show_details\&entry_id=15> [Accessed January 2014].

Akdogan, N. 1991. Dördüncü yönergenin öngördüğü bilanço tablosu ve ülkemizdeki uygulamalarla karşılaştırılması, $\quad$ Avrupa $\quad$ Topluluğuna Entegrasyonda Muhasebe Standartlar1. A.Ü.S.B.F.Yayını No:574:5-61 Türkiye 12. Muhasebe Eğitimi Sempozyumu. Ankara

Akdogan, N. and Tenker, N. 2006. Finansal Tablolar ve Mali Analiz Teknikleri. Ankara: Gazi Publications. 10. edition

Alexander, D., and Nobes, C. 2007. Financial accounting: an international introduction. England: Prentice Hall. 3. edition

Andrei, P. and Bisaschi, A. 2002. Accounting in Italy. L. Orsini, J. P. McAllister ve R.N. Parikh(Editors), World Accounting: ITA-1 - ITA128

Autorité des Normes Comptables. 1999. Regulation 99-02, 29/04/1999 Relating to consolidated accounts of commercial companies and public enterprises. Available from: <http://www.anc.gouv.fr/files/live/sites/anc/files/ contributed/Normes $\% 20$ franca ises/R\%C3\%A9glements/1999/reg1999_02_ang. pdf $>$ [Accessed January 2014].

Autorité des Normes Comptables.2013. Recommendation $\mathrm{n}^{\circ}$ 2013-03 du 7 novembre 2013 relative au format des comptes consolidés des entreprises établis selon les normes comptables internationales (hors établissements du secteur bancaire et organismes d'assurance). Available from:

<http://www.anc.gouv.fr/files/live/sites/anc/files/ contributed/Normes $\% 20$ francaises/Recommanda tions/RECO2010_2014/RECO2013/Reco mmandation_2013_R03/Recommandation_2013_ R03.pdf> [Accessed July 2014].

Beckman, J., Brandes, C., Eierle, B. 2007. German Reporting Practices: An Analysis of Reconciliations from German Commercial Code to IFRS or US GAAP. Advances in International Accounting. Vol. 20: 253-294

Bocqueraz, C. 2010. Chapter 2: France. A Global History of Accounting, Financial Reporting and Public Policy: Europe Studies in the Development of Accounting Thought, Vol. 14A: 37-57

Cairns, D., Massoudi, D. R., Taplin, R. and Tarca, A. 2009. IFRS Fair Value Measurement and Accounting Policy Choice in the United Kingdom and 
Australia. AAA 2009 Mid-Year International Accounting Section (IAS) Meeting. Mart 2010. Available from $<$ http://ssrn.com/abstract=1274024>. [Accessed April 2011].

Catalin Nicolae Albu et al. 2013. Implementation of IFRS for SMEs in Emerging Economies: Stakeholder Perceptions in the Czech Republic, Hungary, Romania and Turkey. Journal of International Financial Management \& Accounting Vol. 24(2): $140-166$

Cameran, M., Pettinicchio, A. 2010. Chapter 4: Italy. A Global History of Accounting, Financial Reporting and Public Policy: Europe Studies in the Development of Accounting Thought, Vol. 14A: 89-106

Christensen, H. B., Nikolaev, V. 2009. Who uses fair value accounting for non-financial assets after IFRS adoption?. Chicago Booth School of Business Research Paper No. 09-12. Available from: <http://faculty.chicagobooth.edu/workshops/acco unting/archi ve/pdf/ChristensenNikolaev 2008_Chicago.pdf> [Accessed April 2011].

Conseil National de la Comptabilité. 2004. Recommendation $\mathrm{N}^{\circ}$ 2004-R.02 du 27 Octobre 2004 relative au format du compte de résultat, tableau des flux de trésorerie et tableau de variation des capitaux propres, des entreprises sous référentiel comptable international (hors entreprises de banque et d'assurance) Available from: <http://www.anc.gouv.fr/files/live/sites/anc/files/ contributed/Normes\%20francaises/R ecommandations/2004r02_format_etat_compte.p df $>$ [Accessed January 2014].

Conseil National de la Comptabilité. 2009. Recommendation $\mathrm{N}^{\circ}$ 2009-R.03 du 02 Juillet 2004 relative au format des etats financiers des entreprises sous référentiel comptable international (hors entreprises de banque et d'assurance) Available from: <http://www.anc.gouv.fr/files/live/sites/anc/files/ contributed/Normes $\% 20$ francaises/R ecommandations/Recomm2009_r03.pdf>

[Accessed January 2014].

Ding, Y., Jeanjean, T. and Stolowy, H. 2008. The impact of firms' internationalization on financial statement presentation: Some French evidence. Advances in Accounting, incorporating Advances in International Accounting 2008(24):145-156

European Council. 1978. Fourth Council Directive of 25 July 1978 based on Article 54 (3) (g) of the Treaty on the annual accounts of certain types of companies (78/660/EEC) Available from: <http://eur-lex.europa.eu/legalcontent/EN/TXT/PDF/?uri=CELEX :31978L0660\&from=EN> [Accessed January 2014].

Haller, A. 2003. Accounting in Germany. P. Walton, A. Haller ve B. Raffournier (Editors), International Accounting: 91-128. London:Thomson. 
Heazlewood, T. 2003. Accounting in Australia. P. Walton,
A. Haller ve B. Raffournier (Editors), International 272-303. London:Thomson.

Hoarau, C. 2003. Accounting in France. P. Walton, A. Haller ve B. Raffournier (Editors), International Accounting: 129-152. London:Thomson.

IASB. 2010. International Financial Reporting Standards: Volume A. United Kingdom: IASCF Department of Publications

Jaafar, A., Mcleay, S. 2007. Country Effects and Sector Effects on the Harmonization of Accounting Policy Choice. ABACUS, Vol. 43(2): 156 - 189

Koc Yalkin, Y. 1991. Dördüncü yönergenin öngördüğü gelir tablosu ve ülkemizdeki uygulamalarla karşılaştırılması, $\quad$ Avrupa $\quad$ Topluluğuna Entegrasyonda Muhasebe Standartları. A.Ü.S.B.F.Yayını No:574:5-61 Türkiye 12. Muhasebe Eğitimi Sempozyumu. Ankara

Kvaal, E., Nobes, C. 2010. International differences in IFRS policy choice: a research note. Accounting and Business Research, Vol. 40(2): 173-187

Kvaal, E., Nobes, C. 2012. IFRS Policy Changes and the Continuation of National Patters of IFRS Practice. European Accounting Review, Vol. 21(2): $343-371$

Marsap, B., Cil Kocyigit, S., Cina Bal, E. 2007. İMKB'de işlem gören gıda, tekstil ve hizmet sektörlerinde faaliyet gösteren şirketlerin finansal tablo dipnotlarında açıklanan muhasebe politikalarının seçilen UFRS'ler açısından incelenmesi. Muhasebe Bilim Dünyası, 2007(4): 99-120

Meek, G. K. 2003. Accounting in the United States. P. Walton, A. Haller ve B. Raffournier (Editors), International Accounting: 66-90. London:Thomson.

Mueller, K. A. III, Riedl, E. J., Sellhorn, T. 2008. Consequences of Voluntary and Mandatory Fair Value Accounting: Evidence Surrounding IFRS Adoption in the EU Real Estate Industry. Harvard Business School Working Paper 09-033. Available from: <http://www.hbs.edu/faculty/Publication\%20File s/09-033.pdf> [Accessed January 2014].

Napier, C. 2010. Chapter 10: United Kingdom. A Global History of Accounting, Financial Reporting and Public Policy: Europe Studies in the Development of Accounting Thought, Vol. 14A: $243-273$

Nobes, C. 2011. IFRS Practices and the Persistence of Accounting System Classification. ABACUS Vol. 47(3): 267-283

Nobes, C. 2013. The Continued Survival of International Differences under IFRS. Accounting and Business Research, Vol. 43(2): 83-111

Page $|80|$ Emerging Markets Journal 
Nobes, C., Parker, R. 2009. Comparative International

Accounting. Prentice Hall, 10. Edition

Organizmo Italiano di Contabilita. 2005. OIC 12

Composizione e schemi del bilancio di esercizio

di imprese mercantili, industriali e di servizi.

Available from:

$<$ http://www.fondazioneoic.eu/wp-

content/uploads/downloads/2010/11/2005-05-

30_P rincipio-12_Schemi-bilancio.pdf>

[Accessed January 2014].

Ozturk, C. 2009. Yerel ve Uluslararas1 Muhasebede Yatırım Amaçlı Gayrimenkul Kavramı ve Türkiye Muhasebe Sistemine Yansımaları. Mali Çözüm. 96:97-126 Available from: $<$ http://archive.ismmmo.org.tr/docs/malicozum/9 6malicozum/5\%20can\%20ozturk.pd> [Accessed December 2014].

Ozturk, C. 2011. Finansal Tabloların Dipnotlarında Sunulan Muhasebe Politikalarının Uluslararası

Finansal Raporlama Standartları Açısından İncelenmesi, Basılmamış Doktora Tezi, Ankara

Simga-Mugan, C. (1995) Accounting in Turkey. The European Accounting Review.

Vol. 4(2): 351-371

Simga-Mugan, C. 2002. Accounting in Turkey. L. Orsini, J. P. McAllister ve R.N. Parikh(Editors), World Accounting: TRK1 - TRK81

Stolowy, H. 2002. Accounting in France. L. Orsini, J. P. McAllister ve R.N. Parikh(Editors), World Accounting: FRA-1 - FRA125
Tarca, A. 2005. International Convergence of Accounting Standards: An Investigation of the Use of IAS "Options" Not Acceptable Under US GAAP. International Journal of Business Studies, 2005(13): 67-86

Walton, P. 2003. Accounting in United Kingdom. P. Walton, A. Haller ve B. Raffournier (Editors), International Accounting: 153-173. London:Thomson.

Zambon, S. 2003. Accounting in Italy. P. Walton, A. Haller ve B. Raffournier (Editors), International Accounting: 195-219. London:Thomson.

a This paper was derived from Can Ozturk's doctorate dissertation(2011) whose title is "Examination of Accounting Policies Presented in the Notes of Financial Statements in terms of International Financial Reporting Standards".

b This paper was presented in the 2014 International Conference for Critical Accounting on April 16, 2014 at Baruch College of the City University of New York in the US. We would like to thank Prof. Anthony Tinker, Prof. Aida Sy and Prof. Jean-Guy Degos for their valuable comments.

${ }^{c}$ This format refers to either article 9 of 4 th directive or US GAAP format.

${ }^{\mathrm{d}}$ This format refers to either article 10 of the 4th directive or British or Australian Anglo-Saxon balance sheet.

${ }^{\mathrm{e}}$ British Anglo-Saxon balance sheet is different from the Australian Anglo-Saxon balance sheet because cash is not at top of the balance sheet and assets are classified from the lowest to the highest liquid assets. The asset side of the British balance sheet was obviously influenced by the article 9 of the 4th Directive.

$\mathrm{f}$ Australian Anglo-Saxon balance sheet is different from the British Anglo-Saxon balance sheet because cash is at top of the balance sheet and assets are classified from the highest to the lowest liquid assets. 